\title{
The Effect of Changes in Funds Budget for Results Against the Changes in Capital Expenditure Budget in District / City in Aceh Province
}

\author{
Sri Mulyati ${ }^{1}$, Nur Afni Yunita ${ }^{1}$, Wahyuddin ${ }^{1}$, Dy Ilham Satria ${ }^{1}$ and Muhammad Yusra ${ }^{1}$ \\ \{srimulyati@unimal.ac.id, wahyuddin@unimal.ac.id \} \\ ${ }^{1}$ Lecturer at the Faculty of Economics and Business, University of Malikussaleh, Indonesia
}

\begin{abstract}
This study aims to find out how the effect of changes in revenue sharing budget on changes in capital expenditure in Districts / Municipalities in Aceh Province. The population in this study is financial report of Local Government which obtained from the data expenditure budget in the form of data on revenue-sharing and capital expenditure in 23 District / Municipalities in Aceh from 2014 to 2016 with total population of 69 LKPD. This method using linear regression analysis as a method of data analysis results of this study demonstrate profit sharing funds (PROFIT SHARING FUNDS (DBH)) Budget Changes affect the Capital Expenditure Budget Changes in District/ Municipalities in Aceh.
\end{abstract}

Keywords: Changes of Budget Capital Expenditure (BM), Budget Changes of Profit Sharing Funds (DBH)

\section{Introduction}

Regional development cannot be realized without physical development in the form of facilities and infrastructure. The physical development can be carried out if the planning is included in the APBD at the expenditure post, especially capital expenditure. Capital expenditure allocation is formed through the budget preparation process. Of course in the allocation of capital expenditure as a support for the development process, the role of the budgeting process is very significant. The use of a performance-based budgeting approach will certainly be increasingly influential in setting goals and outcomes until finally poured into the figures on the APBD capital expenditure post (Aqnisa, 2016).

Balance Fund consists of Profit Sharing Funds (DBH), General Allocation Fund, and the Special Allocation Funds. In addition, there are also other sources that come from regional loans. Therefore, the demand to change the structure of spending becomes stronger, especially in regions that experience low fiscal capacity. (Abdullah and Rona, 2014) explained that changes to the Revenue Sharing Fund are very important because they are free funds used by the Regional Government. This change in expenditure allocation is also aimed at building a variety of public facilities, one of which is through infrastructure. Infrastructure development and the provision of various facilities are carried out to increase the attractiveness of this investment (Darwanto and Yustikasari, 2007). In addition to improving the quality of public services, the Regional Government is obliged to allocate funds in the form of capital expenditure budgets in the APBD to increase fixed assets. This capital expenditure allocation is based on regional needs for facilities and infrastructure, both for the smooth implementation of government duties and for public facilities. So far regional spending has been used more for routine spending which is relatively less productive. 


\section{Literature Review}

Budget is a statement about the estimated performance to be achieved over a certain period of time expressed in financial terms. While budgeting is a process or method for preparing a budget (Mardiasmo, 2009, p. 61).

Budget preparation is part of planning, while budget execution is part of management (Abdullah and Rona, 2014). In its journey, the budget implementation process which is partially not in accordance with the plan must be adjusted again so that the objectives and targets can be implemented properly. According to (Forrester et al., 1992) rebudgeting is "what the government does to revise and renew the budget during the fiscal year". This is an annual budget process to achieve diverse government goals by improving existing budgets to meet continuity, be monitored, accountable, flexible and able to predict things that happen in the future.

\subsection{Changes Capital Expenditure Budget}

According to (Abdullah, 2013) Changes to the budget allocation are the most important part in the APBD changes, especially in the direct expenditure group. (Dougherty and Klase, 2011) emphasized that there were 3 (three) reasons for adjustments to the budget. First, changes to the initial budget are carried out so that the implementation becomes more accurate and on target. Second, changes are made to be more useful in the long-term implementation of the budget cycle both before and in the future. Third, adjustments are made in the current fiscal year due to economic income growth which contributes to an increase in the surplus to adjustments, especially in the capital expenditure sector.

\subsection{Changes in Revenue Sharing Funds}

This fund is a fund sourced from APBN revenues allocated to regions based on percentage figures to fund regional needs in the context of implementing decentralization (Law No.33 of 2004, concerning Financial Balance between the Central Government and Local Governments). Profit Sharing Funds (DBH) transferred by the central government to regional governments consists of 2 types, namely Profit Sharing Funds (DBH) tax and Profit Sharing Funds (DBH) non-tax (Natural Resources) (Dodge et al., 2012).

Based on the new Income Tax Act (Law Number 17 of 2000), starting from 2001 fiscal year, the regions receive profit sharing from personal income tax, namely Article 21 Income Tax and Article 25/29 Personal Income Tax. The stipulation of Individual Income Tax as an object of profit sharing is intended as compensation and alignment for regions that do not have resources of nature (SDA) but provide a large contribution to state revenue (APBN). From the explanation described above, the scheme of thought can be described as follows:

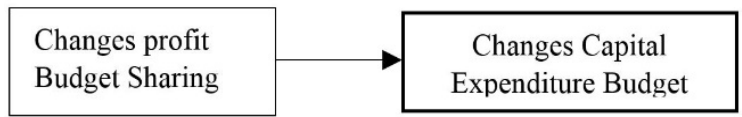

Fig. 1. Thinking Framework Scheme

\section{Methodology}

Population in this study are Local Government Financial Statements (LKPD) for Revenue Sharing Changes and Changes in Capital Expenditures in District / Municipalities in 
Aceh Province from 2014 to 2016 . In this study using census method, namely by taking the entire population. The object of research is the budget the districts / municipalities in Aceh.

The source of data used by the researcher comes from the report of the realization of the district / city budget in the province of Aceh, namely the Fencing of the Amendment of Revenue Sharing and the change in capital expenditure budget obtained from the Aceh Finance Office. The data used in this research is secondary data. Documentation techniques are data retrieval techniques by collecting notes that are the subject of research. In this study the data used is cross section data with the panel data method, the time period from 2014 to 2016 from each regency / city of Local Budget Revenue Expenditure (APBD) data that will be analyzed.

\subsection{Variable Definition and Measurement}

According to (Mahmudi, 2007, p. 96) Capital expenditure is expenditure spent on the purchase of goods or services that are used in the implementation of activities, including the purchase of land, buildings, machinery and vehicles, equipment, installations and networks, furniture, software, and so on.

Revenue Sharing Funds are funds sourced from APBN revenues allocated to regions based on percentage figures to fund regional needs in the context of implementing decentralization (INDONESIA, 2004).

\subsection{Data analysis method}

The analytical method used in this study is linear regression which aims to test and analyze the effect of changes in revenue sharing budget on changes in the capital expenditure of District /Municipalities in Aceh. Data is processed with a Statistical Package for Social Science (SPSS) program. The linear regression model in this study is as follows:

$\mathbf{Y}=\mathbf{a}+\boldsymbol{\beta}_{1} \mathbf{X}_{1}+\varepsilon$

\section{Result And Discussion}

\subsection{Descriptive Results of Research and Analyses Data}

Descriptive statistics used are the average (mean), minimum value, and maximum value. Descriptive statistical results for changes of Profit Sharing Funds (DBH)), and changes in Capital Expenditure Budget (BM), can be seen in Table 4.1 below:

Table 1. Descriptive of Research Data

\begin{tabular}{llllll}
\hline Variable & N & Min & Max & Mean & Std. Deviation \\
\hline $\begin{array}{l}\text { Change of Profit Sharing Funds (DBH) } \\
\text { Change of Budget Capital Expenditure (BM) }\end{array}$ & 69 & - & 457.5 & 38.9 & 6,7 \\
& 69 & 100.0 & 512.0 & 276.5 & 8.6 \\
\hline
\end{tabular}

Based on table 4.1 obtained Amendment of Revenue Sharing Budget for 3 years (from 2014 to 2016), the average value (mean) of 38.9 billion Rupiah, minimum value of (unknown) for North Aceh Regency in 2016 (data not yet reported) while the maximum value for the Amendment of Funds for the Profit Budget is 457.5 billion Rupiah for North Aceh Regency in 2014. The standard deviation value for 3 years is 6.7 . 
The next variable is the Capital Expenditure Budget Change values obtained average (mean) for 3 years amounted to 276.5 billion Rupiah, with a minimum value of 100 billion Rupiah for Langsa at City in 2014, and a maximum value of 512 billion Rupiah gained Central Aceh district on in 2016. The standard deviation value for 3 years was 8.6.

\subsection{Hypothesis Testing Results}

The results of testing hypotheses using linear regression from the effect of Changes in the Budget of Profit Sharing on Changes in the Capital Expenditure Budget in District / City Governments in Aceh can be seen in Table 4.2 following:

Table 2. Research Hypothesis Testing Results

\begin{tabular}{l}
\hline Regression Equation: BMP $=2,669+0,246$ Changes of Profit Sharing Funds (DBH) $\mathrm{P}+\varepsilon$ \\
\hline $\mathrm{R}=0.192$ \\
\hline $\mathrm{R}^{2}=0.037$ \\
\multicolumn{2}{c}{ Source: Data Processed (2018) }
\end{tabular}

Through the results of the SPSS 16 program as shown in Table 5.3, the linear regression equation is obtained as follow:

$\mathrm{BD} \mathrm{P}=2.669+0.246$ PROFIT SHARING FUNDS $(\mathrm{DBH}) \mathrm{P}+\varepsilon$

From this equation it can be seen that the constant value (a) is 2.669, meaning that if the Revenue Sharing Budget Change (X1) is considered constant, then the Capital Expenditure Amendment has a value of 2.669 .

This research is a study by testing hypotheses using linear regression analysis methods. Simple linear analysis method connects one dependent variable with independent variables in a research model.

Regression coefficient variable Amendment Fund Budget Amendment is 0.246, meaning that if the Revenue Sharing Budget Change increases by 1\% then the Amendment of Capital Expenditure Budget will increase by $24.6 \%$. This shows that if the District/City Profit Sharing Fund Budget Change in Aceh has increased, Capital Expenditures will also increase.

\subsection{Influence of Changes in Budget for Revenue Sharing on Changes in Capital Expenditures}

The results showed that the Budget Changes Profit Sharing Funds (DBH) positive influence on the Capital Expenditure Budget Change in District/Municipalities in Aceh. This means that if the Revenue Sharing Budget Amendment increases by Rp. 1 then changes in the Capital Expenditure Budget will also increase by Rp.0.246.

This means that the Amendment of the Profit Sharing Fund Budget also increases the Changes in Capital Expenditures. These results explain that the district / municipality to get a great Profit Sharing Fund (DBH) will tend to have large capital expenditures as well. These results provide strong indications that capital spending behavior will be heavily influenced revenue sources Profit Sharing Fund (DBH). The revenue sharing pattern is carried out with a certain percentage based on the producing region. Local governments can use financial balancing funds, one of which is revenue sharing funds to provide services to the public, which are realized through capital expenditure. So it can be concluded if the change in the 
revenue sharing budget increases, the allocation of capital expenditure budget changes will increase.

The reason for changes in the Regional Expenditure Budget (APBD) can occur due to economic, political and social factors, but generally due to financial factors and fiscal needs. Conceptually, changes in income will affect spending on expenses. APBD changes are a means for the legislature and the executive to change the budget allocation legally. Opportunistic behavior of the legislature and executive when the APBD changes can result in misallocation of government budget. The tendency of Regional Original Revenue which is always increasing when the budget changes, opens up opportunities for the legislature to recommend additional budgets for programs and activities that become its preferences (Abdullah, 2013).

The results of this study are consistent with the results of research conducted by (Abdullah and Rona, 2014) which states that revenue-sharing funds affect changes in regional budget. The results of this study are in accordance with the results of (Dougherty and Klase, 2011) where budget changes are made to be more useful in long-term implementation in the budget cycle both before and in the future, adjustments are made in the current fiscal year due to economic income growth which contributes to an increase in the surplus to adjustments, especially in the capital expenditure sector. This is also in line with the results of research conducted by (Sumarni, 2008) where the General Allocation Fund has a positive effect on Regional Expenditures.

\section{Conclusions}

Based on the discussion of the results that have been described, this study can be concluded that the Amendment of Revenue Sharing Funds affects the Changes in Capital Expenditures in Districts/Municipalities in Aceh.

\section{Reference}

[1] Abdullah, S. (2013) Perubahan APBD | Syukriy Abdullah. Available at: https://syukriy.wordpress.com/2013/04/22/perubahan-apbd/ (Accessed: 15 January 2019).

[2] Abdullah, S. and Rona, R. (2014) 'Pengaruh Sisa Anggaran, PendapatanSendiri Dan Dana Perimbangan terhadap Belanja Modal', IQTISHADIA (Journal of Islamic Economics and Business), 7(1), pp. 179-202. doi: 10.21043/IQTISHADIA.V7I1.1106.

[3] Aqnisa, R. F. (2016) Pengaruh Pendapatan Asli Daerah (PAD), Dana Bagi Hasil (DBH), Dana Alokasi Umum (DAU), dan Dana Alokasi Khusus (DAK) Terhadap Pengalokasian Belanja Modal, Skrispsi. Universitas Muhamadiyah Surakarta.

[4] Darwanto, D. and Yustikasari, Y. (2007) 'Pengaruh Pertumbuhan Ekonomi, Pendapatan Asli Daerah, dan Dana Alokasi Umum terhadap Pengalokasian Anggaran Belanja Modal', in Simposium Nasional Akuntansi X. Makasar.

[5] Dodge, R., Daly, A., Huyton, J. and Sanders, L. (2012) 'The challenge of defining wellbeing', International Journal of Wellbeing, 2(3), pp. 222-235. doi: 10.5502/ijw.v2i3.4.

[6] Dougherty, M. J. and Klase, A. (2011) 'Managerial Surpluses : in The Necessity and the Art of Creating Process West', Public Administration, 63(4), pp. 484-497.

[7] Forrester, J. P., Mullins, D. R., Forrester, P., Mullins, R. and Forrester, J. P. (1992) 'Rebudgeting: he Serial Nature of Municipal', Public Administration Review, 52(5), 
pp. $467-473$.

[8] INDONESIA, U.-U. R. (2004) UNDANG-UNDANG REPUBLIK INDONESIA NOMOR 33 TAHUN 2004.

[9] Mahmudi (2007) Analisis Laporan Keuangan Pemerintah Daerah. Yogyakarta: STIM YKPN.

[10] Mardiasmo, M. (2009) Akuntansi Sektor Publik Akuntansi Keuangan Daerah. Jakarta: Salemba Empat.

[11] Sumarni, S. (2008) Pengaruh Pendapatan Asli Daerah, Dana Alokasi Umum dan Dana Alokasi Khusus terhadap Alokasi Belanja Modal Daerah Kabupaten/Kota di Provinsi D.I.Yogyakarta. Yogyakarta. 
